\title{
Study on Halide lons Selectivity of Nuclear Grade Anion Exchange Resin Auchlite ARA-9366
}

\author{
P. U. Singare ${ }^{*}$ A. N. Patange \\ Department of Chemistry, Bhavan's College, Munshi Nagar, Andheri (West), Mumbai 400058, India \\ *E-mail address: pravinsingare@gmail.com
}

\begin{abstract}
The selectivity behaviour of nuclear grade anion exchange resin Auchlite ARA-9366 in chloride form towards iodide and bromide ions in the solution was studied. The trend in selectivity of the resin was predicted on the basis of thermodynamics of $\mathrm{Cl}^{-} / \mathrm{I}^{-}$and $\mathrm{Cl}^{-} / \mathrm{Br}^{-}$uni-univalent ion exchange reactions. It was observed that the equilibrium constants $K$ values for $\mathrm{Cl}^{-} / \mathrm{I}^{-}$ion exchange reaction were higher than that calculated for $\mathrm{Cl}^{-} / \mathrm{Br}^{-}$exchange under identical experimental conditions. Also the enthalpy values for the two uni-univalent ion exchange reactions were calculated

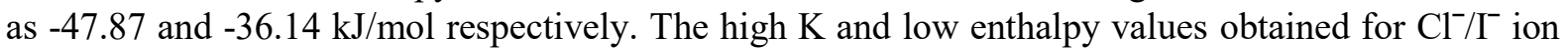
exchange reaction as compared to that obtained during $\mathrm{Cl}^{-} / \mathrm{Br}^{-}$exchange supports higher selectivity of the resin towards iodide ions as compared to that towards bromide ions, when both the ions are present in the same solution.
\end{abstract}

Keywords: selectivity; ion exchange reactions; halide ions; nuclear grade resins; anion exchange resins; enthalpy; equilibrium constant; Auchlite ARA-9366

\section{INTRODUCTION}

Ion exchange resins having different properties, varied formulation range are manufactured commercially for large scale industrial applications in food, pharmaceutical, chemical, nuclear industry etc [1]. The main advantages of synthetic organic ion exchange resins are their high capacity, wide applicability, wide versatility and low cost relative to some synthetic inorganic media. Organic ion exchange resins have been developed over a much longer period of time than the selective inorganic ion exchangers that are now becoming available in commercial quantities and they can now meet the demands of the nuclear industry. In number of cases, for specific physical and chemical reasons, organic resins cannot be replaced by inorganic ion exchangers and organic ion exchange resins continued to be used globally. Organic based ion exchange resins play a very vital role in nuclear industries for removal of radionuclide and also in chemical decontamination or cleaning processes [2-6]. The organic ion exchange resins are very effective at transferring the radioactive content of a large volume of liquid into a small volume of solid and have proved to be reliable and effective for the control of both the chemistry and radiochemistry of water coolant systems at nuclear power plants and also for processing some liquid radioactive waste. In recent years tremendous work on development of new organic based ion exchangers 
for specific applications is done and various technological aspects of ion exchange have been regularly studied to improve their performance in various technical applications [7-15]. By taking advantage of the fact that, under certain conditions, ion exchange media has a greater affinity for certain ionic species than for others, a separation of these species can be made [16]. However presence of chemically similar ionic species in the liquid waste will create difficulty in selection of suitable ion exchange media. If low cost general ion exchange media are used, large volumes may be required, leading to larger volumes of waste to treat and dispose of. Higher cost ion specific exchangers may be a better choice, especially when the extra cost of the media is more than offset by the reduction in the total cost for the treatment and subsequent storage and/or disposal of the spent media.

Hence in the present investigation attempts are made to understand the selectivity behaviour of nuclear grade anion exchange resin Auchlite ARA-9366 towards the iodide and bromide ions in the solution on the basis of thermodynamics of uni-univalent ion exchange reaction.

\section{EXPERIMENTAL}

The ion exchange resin Auchlite ARA-9366 as supplied by the manufacturer (Auchtel Products Ltd., Mumbai, India) was the strongly basic nuclear grade anion exchangers in hydroxide form. The resin was having polystyrene matrix having quaternary ammonium functional group. The particle size of the resin was $0.3-1.0 \mathrm{~mm}$, having moisture content of $50 \%$, operating $\mathrm{pH}$ range of $0-14$ and maximum operating temperature of $60.0{ }^{\circ} \mathrm{C}$. For present investigation, the resin grains of 30-40 mesh size were used. The soluble impurities of the resin were removed by repeated soxhlet extraction using water and occasionally with distilled methanol to remove non-polymerized organic impurities. In order to bring about complete conversion of resins in chloride form, the resins were conditioned with $10 \%$ potassium chloride solution in a conditioning column. The resins were washed with distilled deionised water until the washings were free from chloride ions. The resins in chloride form were air dried over $\mathrm{P}_{2} \mathrm{O}_{5}$ and used for further studies. The exchange capacity of ion exchange resins was experimentally determined by the standard method [17] using sodium nitrate and titrating against standard silver nitrate solution. Ion exchange resins $(0.500 \mathrm{~g})$ in chloride form were equilibrated with iodide ion solution of different concentrations at a constant temperature of $35.0^{\circ} \mathrm{C}$ for $3 \mathrm{~h}$. From the results of kinetics study reported earlier [18-47]; it was observed that this duration was adequate to attain the ion exchange equilibrium. After 3 $\mathrm{h}$, the iodide ion solutions in equilibrium with ion exchange resins in chloride form were analyzed for their chloride and iodide ion concentrations by potentiometric titration with standard $0.1 \mathrm{M}$ silver nitrate solution. From the results the equilibrium constant $K$ for the reaction

$$
\mathrm{R}-\mathrm{Cl}+\mathrm{I}^{-}{ }_{(\mathrm{aq})} \rightleftharpoons \mathrm{R}-\mathrm{I}+\mathrm{Cl}^{-}{ }_{(\mathrm{aq})}
$$

was determined at $35.0{ }^{\circ} \mathrm{C}$. The equilibrium constants $K$ for the above $\mathrm{Cl}^{-} / \mathrm{I}^{-}$system was determined for different temperatures in the range of $30.0^{\circ} \mathrm{C}$ to $45.0^{\circ} \mathrm{C}$.

Similar study was performed by equilibrating resins $(0.500 \mathrm{~g})$ in chloride form with bromide ion solution of different concentrations at a constant temperature of $35.0^{\circ} \mathrm{C}$ for $3 \mathrm{~h}$. After $3 \mathrm{~h}$, the bromide ion solutions in equilibrium with ion exchange resins in chloride form were 
analyzed for their chloride and bromide ion concentrations by potentiometric titration with standard $0.1 \mathrm{M}$ silver nitrate solution. From the results the equilibrium constant $K$ for the reaction

$$
\mathrm{R}-\mathrm{Cl}+\mathrm{Br}^{-}{ }_{(\mathrm{aq})} \rightleftharpoons \mathrm{R}-\mathrm{Br}+\mathrm{Cl}^{-}{ }_{(\mathrm{aq})}
$$

was determined at $35.0{ }^{\circ} \mathrm{C}$. The equilibrium constants $K$ for the above $\mathrm{Cl}^{-} / \mathrm{Br}^{-}$system was determined for different temperatures in the range of $30.0^{\circ} \mathrm{C}$ to $45.0^{\circ} \mathrm{C}$.

In the present study, a semi-micro burette having an accuracy of $0.02 \mathrm{~mL}$ was used in the titrations against silver nitrate solution. The titration readings were accurate to $\pm 0.02 \mathrm{~mL}$. Considering the magnitude of the titre values, the average equilibrium constants reported in the experiment are accurate to $\pm 3 \%$.

\section{RESULTS AND DISCUSSION}

The equilibrium constant for reactions 1 and 2 can be written as

$$
K=\frac{\mathrm{C}_{\mathrm{R}-\mathrm{X}} \cdot \mathrm{C}_{\mathrm{Cl}^{-}}}{\left(A-\mathrm{C}_{\mathrm{R}-\mathrm{X}}\right) \cdot \mathrm{C}_{\mathrm{X}^{-}}}
$$

here, $A$ is the ion exchange capacity of the resin and $\mathrm{X}^{-}$represents $\mathrm{I}^{-}$and $\mathrm{Br}^{-}$ions. For different concentrations of $\mathrm{X}^{-}$ions in solution at a given temperature, $K$ values were calculated and an average $K$ value for this set of experiments was found (Tables 1,2). Similar $K$ values were calculated for the $\mathrm{Cl}^{-} / \mathrm{I}^{-}$and $\mathrm{Cl}^{-} / \mathrm{Br}^{-}$system at different temperatures (Table 3).

Table 1. Equilibrium constant for the ion exchange reaction (1) using Auchlite ARA-9366 resin. Amount of the ion exchange resin in chloride form $=0.500 \mathrm{~g}$, Ion exchange capacity $=2.3 \mathrm{meq} . / 0.5 \mathrm{~g}$, Temperature $=35.0^{\circ} \mathrm{C}$.

\begin{tabular}{|c|c|c|c|c|c|c|}
\hline System & $\begin{array}{c}\text { Initial conc. } \\
\text { of iodide } \\
\text { ion (M) }\end{array}$ & $\begin{array}{c}\text { Final conc. } \\
\text { of iodide } \\
\text { ions (M) } \\
\mathrm{C}_{\mathrm{I}^{-}}\end{array}$ & $\begin{array}{c}\text { Change } \\
\text { in iodide } \\
\text { ion conc. }\end{array}$ & $\begin{array}{c}\text { Conc. of } \mathrm{Cl}^{-} \\
\text {ions } \\
\text { exchanged } \\
(\mathrm{M}) \\
\mathrm{C}_{\mathrm{Cl}^{-}}\end{array}$ & $\begin{array}{c}\text { Amount of iodide } \\
\text { ions } \\
\text { exchanged on the } \\
\text { resin } \\
\text { meq./0.5 g } \\
\mathrm{C}_{\mathrm{RI}}\end{array}$ & $\begin{array}{c}\text { Equilibrium } \\
\text { constant }(K) \\
\mathrm{x} 10^{-2}\end{array}$ \\
\hline 1 & 0.009 & 0.0013 & 0.0077 & 0.0077 & 0.385 & 119.08 \\
\hline 2 & 0.023 & 0.0120 & 0.0110 & 0.0110 & 0.550 & 28.81 \\
\hline 3 & 0.047 & 0.0362 & 0.0108 & 0.0108 & 0.540 & 9.15 \\
\hline 4 & 0.072 & 0.0602 & 0.0118 & 0.0118 & 0.590 & 6.76 \\
\hline 5 & 0.094 & 0.0832 & 0.0108 & 0.0108 & 0.540 & 3.98 \\
\hline \multicolumn{7}{|c|}{ Average K } \\
\hline
\end{tabular}


Table 2. Equilibrium constant for the ion exchange reaction (2) using Auchlite ARA-9366 resin. Amount of the ion exchange resin in chloride form $=0.500 \mathrm{~g}$, Ion exchange capacity $=2.3 \mathrm{meq} . / 0.5 \mathrm{~g}$, Temperature $=35.0^{\circ} \mathrm{C}$.

\begin{tabular}{|c|c|c|c|c|c|c|}
\hline System & $\begin{array}{c}\text { Initial conc. } \\
\text { of bromide } \\
\text { ion (M) }\end{array}$ & $\begin{array}{c}\text { Final conc. } \\
\text { of bromide } \\
\text { ions (M) } \\
\mathrm{C}_{\mathrm{Br}^{-}}\end{array}$ & $\begin{array}{c}\text { Change } \\
\text { in bromide } \\
\text { ion conc. }\end{array}$ & $\begin{array}{c}\text { Conc. of } \\
\mathrm{Cl}^{-} \text {ions } \\
\text { exchanged } \\
(\mathrm{M}) \\
\mathrm{C}_{\mathrm{Cl}^{-}}\end{array}$ & $\begin{array}{c}\text { Amount of } \\
\text { bromide ions } \\
\text { exchanged } \\
\text { on the resin } \\
\text { meq./0.5 g } \\
\mathrm{C}_{\mathrm{RBr}}\end{array}$ & $\begin{array}{c}\text { Equilibrium } \\
\text { constant }(K) \\
\times 10^{-2}\end{array}$ \\
\hline 1 & 0.0092 & 0.0038 & 0.0054 & 0.0054 & 0.270 & 18.90 \\
\hline 2 & 0.0230 & 0.0156 & 0.0074 & 0.0074 & 0.370 & 9.09 \\
\hline 3 & 0.0484 & 0.0398 & 0.0086 & 0.0086 & 0.430 & 4.97 \\
\hline 4 & 0.0724 & 0.0702 & 0.0022 & 0.0022 & 0.110 & 0.16 \\
\hline 5 & 0.0958 & 0.0932 & 0.0026 & 0.0026 & 0.130 & 0.17 \\
\hline \multicolumn{7}{|c|}{ Average $K$} \\
\hline
\end{tabular}

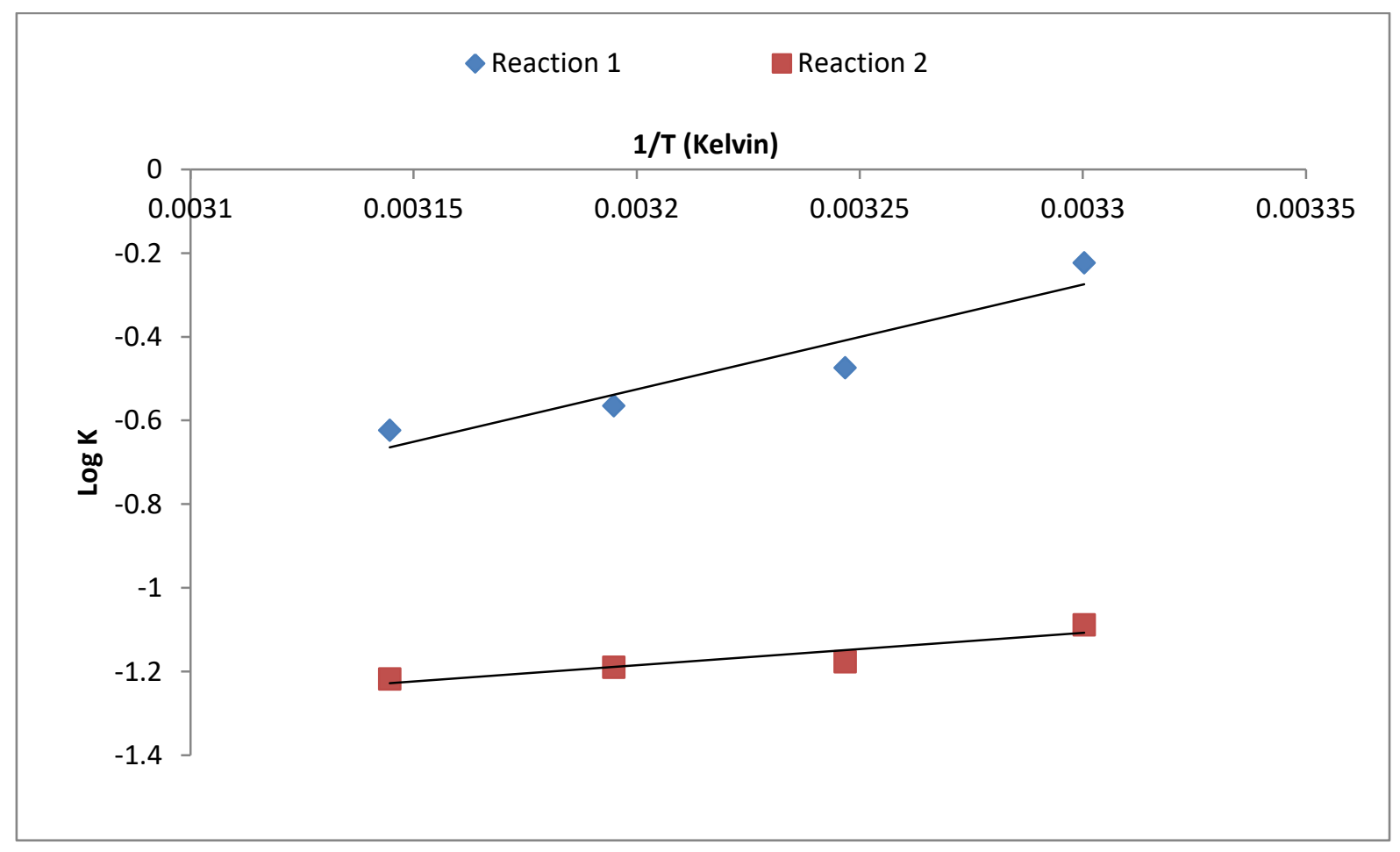

Figure 1. Effect of temperature on equilibrium constant of uni-univalent ion exchange Reactions performed by using Auchlite ARA-9366 resins.

The $\log K$ values were plotted against 1/T (in Kelvin), which gives a straight line graph (Figure 1) from the slope of this graph enthalpy values of the ion exchange reactions 1 and 2 were calculated (Table 3). 
Table 3. Thermodynamics of ion exchange reactions using Auchlite ARA-9366 ion exchange resin.

\begin{tabular}{|c|c|c|c|c|c|c|c|c|}
\hline Reactions & \multicolumn{3}{|c|}{1} & \multicolumn{3}{c|}{2} \\
\hline Temperature $\left({ }^{\circ} \mathrm{C}\right)$ & 30.0 & 35.0 & 40.0 & 45.0 & 30.0 & 35.0 & 40.0 & 45.0 \\
\hline $\begin{array}{c}\text { Equilibrium Constant } \\
(K) \times 10^{-2}\end{array}$ & 59.77 & 33.56 & 27.20 & 23.77 & 8.15 & 6.66 & 6.46 & 6.06 \\
\hline Enthalpy $(\mathrm{kJ} / \mathrm{mol})$ & \multicolumn{3}{|c|}{-47.87} & \multicolumn{4}{c|}{-36.14} \\
\hline
\end{tabular}

Bonner and Pruett [45] studied the temperature effect on uni-univalent exchanges involving some divalent ions. In all divalent exchanges, the equilibrium constant decreases with rise in temperature resulting in exothermic reactions. Similar results were obtained in the present investigation for Auchlite ARA-9366 resins during $\mathrm{Cl}^{-} / \mathrm{I}^{-}$and $\mathrm{Cl}^{-} / \mathrm{Br}^{-}$uni-univalent ion exchange reactions having the enthalpy values of -47.87 and $-36.14 \mathrm{~kJ} / \mathrm{mol}$ respectively (Table 3). The equilibrium constants $K$ for $\mathrm{Cl}^{-} / \mathrm{I}^{-}$ion exchange reaction were found to be higher than that for $\mathrm{Cl}^{-} / \mathrm{Br}^{-}$exchange under identical experimental conditions (Table 3). Similarly, the enthalpy value for $\mathrm{Cl}^{-} / \mathrm{I}^{-}$ion exchange reaction was lower than that calculated for $\mathrm{Cl}^{-} / \mathrm{Br}^{-}$ion exchange reaction. The relatively high $K$ and low enthalpy value obtained for $\mathrm{Cl}^{-} / \mathrm{I}^{-}$ion exchange reaction indicate higher selectivity of the resin towards iodide ions as compared to that towards bromide ions, when both the ions are present in the same solution.

\section{CONCLUSION}

Ion exchange technology is widely being used for separation of particular ionic species in presence of other. The selection of suitable ion exchange material is still more critical when the process involves separation of two or more chemically same ionic species in the solution. Under such critical conditions the present experimental technique will be useful in deciding about the selection of suitable ion exchange material. The technique used here can be extended further to standardise the process parameters in order to bring about the efficient separation of the desired ionic species from the solution.

\section{References}

[1] Marhol, M., Comprehensive Analytical Chemistry, Ion Exchangers, XIV (1982) 117-160.

[2] Samanta, S.K., Ramaswamy, M., Misra, B.M., Sep. Sci. Technol. 27 (1992) 255-267.

[3] Samanta, S.K., Ramaswamy, M., Sen, P., Varadarajan, N., Singh, R.K., Removal of radiocesium from alkaline IL waste, Natl Symp. On Management of Radioactive and Toxic Wastes (SMART-93), Kalpakkam, 1993, Bhabha Atomic Research Centre, Bombay, 1993, 56-58.

[4] Samanta, S.K., Theyyunni, T.K., Misra, B.M., J. Nucl. Sci. Technol. 32 (1995) 425-429. 
[5] Kulkarni, Y., Samanta, S.K., Bakre, S.Y., Raj, K., Kumra, M.S., Process for treatment of intermediate level radioactive waste based on radionuclide separation, Waste Management'96 (Proc. Int. Symp Tucson, AZ, 1996), Arizona Board of Regents, Phoenix, AZ (1996) (CD-ROM).

[6] Bray, L.A., Elovich, R.J., Carson, K.J., Cesium Recovery using Savannah River Laboratory Resorcinol-formaldehyde Ion Exchange Resin, Rep. PNL- 7273, Pacific Northwest Lab., Richland, WA (1990).

[7] Singare, P.U., Lokhande, R.S., Madyal, R.S., Open Journal of Physical Chemistry 1(2) (2011) 45-54.

[8] Singare, P.U., Lokhande, R.S., Madyal, R.S., Rus. J. Gen.Chem. 80(3) (2010) 527-532.

[9] Tomoi, M., Yamaguchi, K., Ando, R., Kantake, Y., Aosaki, Y., Kubota, H., J. Appl. Poly. Sci. 64(6) (1997) 1161-1167.

[10] Zhu, L., Liu, Y., Chen, J., Ind. Eng. Chem. Res. 48(7) (2009) 3261-3267.

[11] Kumaresan, R., Sabharwal, K. N., Srinivasan, T. G., Vasudeva Rao, P.R., Dhekane, G., Solvent Extraction and Ion Exchange 24(4) (2006) 589-602.

[12] Cortina, J. L., Warshawsky, A., Kahana, N., Kampel, V., Sampaio, C. H., Kautzman, R.M., Reactive and Functional Polymers 54(1-3) (2003) 25-35.

[13] Zaidi, S.A.R., Shah, G.B., Macromolecular chemistry and physics 201(18) (2000) 2760-2764.

[14] Sugii, A., Ogawa, N., Nozaki, Y., Haratake, M., Reactive Polymers, Ion Exchangers, Sorbents, 8(1) (1988) 3-6.

[15] Yergozhin, Ye.Ye., Abdrakhmanova, I.K., Menligaziyev, Ye.Zh., Polymer Science U.S.S.R. 23(11) (1981) 2671-2678.

[16] Ion Exchange Technology I-Theory and Materials, Inamuddin, M.Luqman (Eds.), ISBN 978-94-007-1700-8 (eBook), DOI 10.1007/978-94-007-1700-8, Springer Dordrecht Heidelberg New York, London, 2012.

[17] Jeffery, G. H., Basset, J., Mendham, J., Denney, R. C., Ion Exchange, in Vogel's Textbook of Quantitative Chemical Analysis, 5th Ed., ELBS, Longman Scientific and Technical, England, (1989) pp. 208.

[18] Singare, P.U., Diffusion Fundamentals Online Journal 19(4) (2013) 1-21.

[19] Singare, P.U., Int. J. Nucl. Energy Sci. and Technol. 8(2) (2014) 157-170.

[20] Singare, P.U., J. Nucl. Energy Science and Power Generation Technology 2(2) (2013) 1-6.

[21] Singare, P.U., International Letters of Chemistry, Physics and Astronomy 13 (2013) $37-49$.

[22] Singare, P.U., International Letters of Chemistry, Physics and Astronomy 13 (2013) $50-62$.

[23] Singare, P.U., International Letters of Chemistry, Physics and Astronomy 13 (2013) 63-76. 
[24] Singare, P.U., International Letters of Chemistry, Physics and Astronomy 13 (2013) 77-89.

[25] Singare, P.U., International Letters of Chemistry, Physics and Astronomy 12 (2013) $1-13$.

[26] Singare, P.U., International Letters of Chemistry, Physics and Astronomy 12 (2013) 14-27.

[27] Singare, P.U., International Letters of Chemistry, Physics and Astronomy 6 (2013) 1-5.

[28] P. U. Singare, A. N. Patange, International Letters of Chemistry, Physics and Astronomy 6 (2014) 1-7.

[29] P.U. Singare, A.N. Patange, International Letters of Chemistry, Physics and Astronomy 6 (2014) 8-15.

[30] Singare, P.U., Inter. J. Materials and Chemistry 2(4) (2012) 151-157.

[31] Singare, P.U., Phys. Chem. 2(4) (2012) 48-55.

[32] Singare, P.U., Science and Technology 2(5) (2012) 135-141.

[33] Singare, P.U., American J. Fluid Dynamics 2(5) (2012) 71-77.

[34] Singare, P.U., American J. Chem. 2(5) (2012) 263-270.

[35] Singare, P.U., Int. J. Composite Materials 2(6) (2012) 119-126.

[36] Singare, P.U., J. Nuclear and Particle Physics 2(5) (2012) 119-125.

[37] Singare, P.U., Frontiers in Science 2(6) (2012) 235-242.

[38] Singare, P.U., Advances in Anal. Chem. 2(5) (2012) 53-59.

[39] Singare, P.U., American J. Poly. Sci. 2(5) (2012) 115-121.

[40] Singare, P.U., Phys. Chem. 2(3) (2012) 37-42.

[41] Singare, P.U., Journal of Radioanalytical and Nuclear Chemistry 299 (2014) 591-598.

[42] Singare, P.U., Nuclear Engineering and Technology, 46(1), 93-100 (2014).

[43] Singare, P.U., Journal of Nuclear Engineering \& Technology 4(1) (2014) 13-24.

[44] Singare, P.U., Journal of Nuclear Engineering \& Technology 4(1) (2014) 1-12.

[45] Singare, P.U., Journal of Nuclear Engineering \& Technology 3(2) (2013) 14-24.

[46] Singare, P.U., Journal of Nuclear Engineering \& Technology 3(3) (2013) 1-11.

[47] Bonner, O.D., Pruett, R.R., J. Phys. Chem. 63 (1959) 1420. 